\title{
Christiansens kunstige hofteledd - kva var det som gjekk gale?
}

\begin{abstract}
SAMANDRAG Moderne artroplastikkar er utan tvil det største bidraget frå ortopedisk kirurgi i den medisinske utviklinga. Engelskmannen John Charnley (1911-82) har hovudæra for dei gode resultata med totalprotesar i hofteledd. Nordmannen Tor Aas Christiansen (1917-81) har òg en plass i denne historia. Han ville betre resultata av operativ handsaming av dislokerte mediale lårhalsfrakturar hjå eldre og konstruerte i 1960-åra ein hemiprotese. Seinare laga han òg ein totalprotese til hofteleddet. Det viste seg etter kvart at protesane ikkje var så vellukka. Om lag 6500 Christiansen-protesar vart likevel sette inn i Noreg før ein prospektiv Charnley-versus-Christansen-studie ved Kysthospitalet i Hagevik sette endeleg stogg for protesen hans i 1983. Studien førte indirekte til at det vart oppretta eit nasjonalt hofteregister i 1987, no Nasjonalt register for leddproteser, på Haukeland universitetssjukehus. Med bakgrunn i personleg samarbeid og kontakt med Christiansen frå 1963, og ut frå originalteikningar og korrespondanse frå Polaris Fabrikker i Sandnes, vil me fortelje om Christiansens hemi- og totalprotesar. Desse utgjer ein viktig del av historia om norsk hofteprotesekirurgi.
\end{abstract}

Tor Aas Christiansen (1917-1981) (fig 1) byrja si sjukehusteneste i Porsgrunn i 1949. Etter kort tid ved Kysthospitalet i Hagevik heldt han fram ved patologisk avdeling ved Rikshospitalet, og i åra 1954-63 var han ved sjukehus i Sarpsborg, Rogaland og Aker. Han hadde soleis ei solid utdaning i generell kirurgi og patologi då han vart tilsett som reservelækjar ved Drammen sykehus i 1963. I 1965 vart han overlækjar ved kirurgisk avdeling ved sjukehuset i Kongsberg. Han arbeidde der til han døydde brått i 1981, berre 64 år gamal (1).

Med heilhjarta kollegial støtte frå kirurgisk avdeling ved Drammen sykehus, med overlækjar Kaare Liavaag (1908-81) i spissen, byrja Christiansen tidleg i 1960åra å lage til ein ny type hofteprotese. Med god støtte frå medisinsk og teknisk nærmiljø makta han å utvikle ein ny protese utanfor universitetsmiljøet. I denne artikkelen vil vi vise den vanskelege vegen fram til Christiansens hemi- og totalprotesar og freiste å svare på kvifor det gjekk gale.

\section{Kunnskapsgrunnlag}

Denne artikkelen byggjer på personleg kontakt mellom Christiansen og Knut Rasmus Ramstad heilt frå Ramstad vart tilsett som assistentlækjar ved Drammen sykehus i 1963. Einar Sudmann lærde Christiansen å kjenne via Ramstad i 1967 og korresponderte sidan stort sett med han per brev, mellom anna med kommentarar og retting av manuskriptutkasta hans. Lars Birger Engesæter lærde Christiansen å kjenne på faglege møte. Artikkelen byggjer òg på originalteikningar og korrespondanse i mappa for Christiansen-protesen ved Polaris Fabrikker i Sandnes.

\section{Mediale collumfrakturar}

I vårt land vart hemiprotesar tekne i bruk som primærhandsaming av lårhalsbrot hjå enkelte eldre pasientar i midten av 1950åra, men dei fleste mediale lårhalsbrota vart nagla med den trevenga Smith-PetersenJohansson-naglen. På mange avdelingar kom det ikkje sjeldan postoperativ redislokasjon av brotet, så også på kirurgisk avdeling, Drammen sykehus, tidleg i 1960åra (2). Heller ikkje Austin Moores hemiprotesar var utan problem, for enkelte stammar losna, og hjå mange pasientar gav metallhoftekula erosjon av acetabulum og protrusio acetabuli.

Christiansen, som då var reservelækjar ved sjukehuset, meinte at multiple gjengepinnar perifert i collum/caput ville hindre rotasjon i frakturen. Slike fekk han laga til ved ein lokal verkstad i Drammen. Gjengedelen, som skulle stå i caput femoris, vart sveisa på ein rustfri, glatt stålpinne. Etter ei tid, ved postoperativ belastning, knakk desse «heimelaga» gjengepinnane i sveisepunktet. Gjengedelen stod att i caput. Multiple perifere gjengepinnar av tilsvarande type vart sidan sett i system av Deyerle (3).

For å redusere slitasjen i acetabulum, og med bakgrunn i Pauwels' klassiske biomekaniske arbeid om mediale collumfrakturar (4), konstruerte Christiansen så ein hemihofteprotese der ei hoftekule av plast artikulerte med eit tapplager (5).

\section{Christiansens hemiprotese}

Eit tapplager (fig 2, fig 3a) var ein kjend mekanisk konstruksjon som kunne dimensjonerast for dei store kreftene eit hofteledd vert utsett for. I Christiansens hemiprotese vart vinkelen mellom den sylindriske lager-

\section{Einar Sudmann}

einar@sudmann.no

Sivlevegen 2

Voss

Knut Rasmus Ramstad

Gjerdåsveien 9

Bodø

Lars Birger Engesæter

Ortopedisk klinikk

Haukeland universitetssjukehus

Engelsk omsetjing på www.tidsskriftet.no 


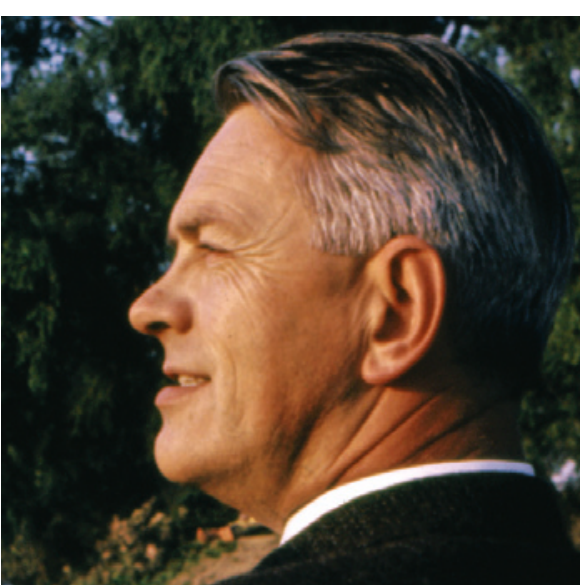

Figur 1 Tor Aas Christiansen i 1966. Foto: Knut Rasmus Ramstad

tappen og proteseskaftet empirisk sett til $115^{\circ}$, noko som gav tilfredsstillande lagring for rørsler i sagittalplanet - fleksjon og ekstensjon. Dermed vart det meste av rørslene i hofteleddet mellom den kunstige hoftekula og acetabulum overførde til tapplageret.

Ved radiologiske funksjonsbilete med ein liten metallmarkør i plasthoftekula kunne ein vise at denne låg $\mathrm{i}$ ro ved fleksjon/ekstensjon i hofteleddet (6). Funna vart sidan verifiserte med cineradiografi (7). Men ved abduksjon, adduksjon og rotasjon fungerte protesen som ein vanleg hemiprotese med fast hoftekule.

Christiansen fekk norsk og amerikansk patent på hemiprotesen sin med prioritets- dato 26. mai 1965, respektive 24. mai 1966. Dei første prototypane vart laga på Fadum tekniske i Drammen av ingeniørane Robert Johansen og Knut Nilsen. Ifylgje førstesideoppslag i Fædrelandsvennen vart protesen frå hausten 1968 produsert ved AS Nymo, som vesentleg laga maritime artiklar (8). For å ta hand om produksjon og distribusjon vart aksjeselskapet AS Joni registrert 13. september 1966.

I 1965 vart dei første hemiprotesane til Christiansen tekne i bruk i Drammen ved dislokerte mediale collumfrakturar hjå pasientar over 70 år. Hoftekula var av polytetrafluoretylen (teflon), eit materiale som viste seg å vere ueigna. Christiansen, ein av forfattarane (Ramstad) og ingeniør Nilsen vitja difor John Charnley (1911-82) på Wrightington Hospital nær Wigan i England 19. september 1966. Charnley hadde nemleg brukt teflon til ei kunstig hofteskål til dei første totalprotesane sine (9). Men desse pasientane måtte reopererast, for hofteskåla vart fort utsliten (fig 4) og teflonpartiklane førde til sver vevsreaksjon. Charnley slutta difor med teflon i november $1962(10,11)$. Deretter nytta han ein sementert stamme med ei lita, fast hoftekule mot ei tjukk, fastsementert hofteskål av polyetylen med høg molekylvekt (HMWP) (fig 4). I boka Low friction arthroplasty of the hip (12) viste han at dette gav svært gode langtidsresultat, og denne protesen vart gullstandarden alle totalprotesar sidan vart vekta mot.

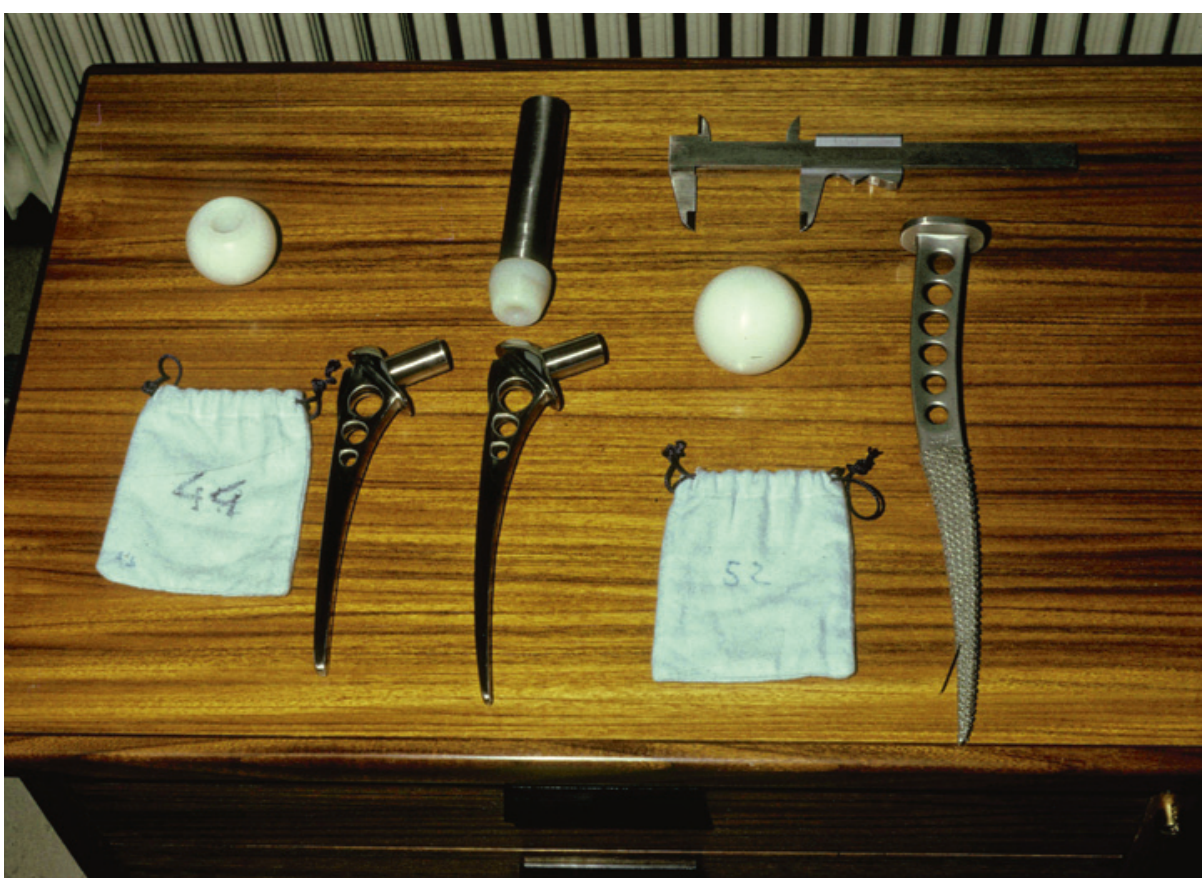

Figur 2 Christiansens hemiprotese i 1967. Hoftekuler av polyetylen, diameter 44 mm og 52 mm, utan stålkappe. Stammar av ulik storleik, rasp og dor til å banke desse ned i femurskaftet. Under operasjonen måtte ein ha eit sterilt skyvlær for å finne diameteren til det caput femoris som operatøren fjerna. Foto: Einar Sudmann
Då nordmennene vitja Charnley, var Christiansen berre interessert i hemiprotesar, ikkje totalprotesar. Dessutan var dei på den tida skeptiske til å feste femurstammen i femurskaftet med sement, men ikkje til valet av stål mot polyetylen.

I 1967 bytte fylgjeleg Christiansen teflonhoftekula på hemiprotesen med ei tilsvarande hoftekule av polyetylen med høg molekylvekt (fig 2, fig 3a) (5). Men med vevsreaksjonen teflonhoftekulene utløyste friskt i minne gjorde ein av oss (Ramstad) framlegg om å leggje ei kappe av $2 \mathrm{~mm}$ polert rustfritt stål utanpå polyetylenkula. Dette vart gjort ved Polaris Fabrikker i Sandnes (fig 3b). Stålkappa vart av økonomiske grunnar ikkje søkt patentert. Dei første 150 av 500 tinga hoftekuler med rustfri stålkappe og ein ytre diameter på 44-54 mm vart sende frå Polaris til Joni 21. september 1968. Desse hoftekulene gav mykje betre resultat enn polyetylenhoftekuler utan stålkappe (13).

Ramstad brukte Christiansens hemiprotese i ein tiårsperiode frå 1968 hjå 200 pasientar ved Sentralsykehuset i Bodø. Ved etterundersøking av dette materialet, med ei median observasjonstid på 14 år, var 42 pasientar, med 44 opererte hofter, framleis i live og i stand til å møte til etterundersøking. 25\% av protesestammane var då losna (14). Alle hadde hoftekule av polyetylen med stålkappe, bortsett frå sju med hoftekule av polyoksymetylen (Delrin), produsert av Benoist Girard \& Co. Dette var eit fransk Howmedica Inc-selskap som overtok produksjonen av Christiansens hemiprotese i 1971.

\section{Hemiprotese med kulelager}

Christiansen patenterte ikkje berre ein tapp og tapplageret, men òg ein heilstøypt protesestamme med eit lite caput på stammen à la Charnley mot ei laus hoftekule (ball and socket joint), med andre ord ein bipolar hemiprotese (15). Dette prinsippet vart sidan nytta av professor M. Devas ved Royal East Sussex Hospital, Hastings, for å unngå acetabular erosjon (16).

I eit seinare ti års prospektivt arbeid frå dette sjukehuset, med 561 dislokerte lårhalsbrot hjå 546 pasientar, fann dei knapt betre kliniske resultat jamført med konvensjonelle hemiartroplastikkar med fast hoftekule, men acetabularerosjonen vart halvert (17). Denne Charnley-Hastings-protesen er sidan noko modifisert, men er i prinsipp den same i dag (fig 3d). Han er no mykje nytta som primærhandsaming ved fractura colli femoris hjå eldre (18).

\section{Den første totalprotesen i Noreg}

På vårparten i 1969, som nytilsett assistentlækjar ved Sophies Minde Ortopedisk Hospital, prøvde ein av forfattarane (Sudmann) 
utan hell å overtale professor Ivar Alvik (1905-71) til å bruka Charnley-protesar heller enn artrodese ved hofteleddsartrose.

Så ein ettermiddag kom Alvik og sa: «Sudmann, i morgon assisterer du meg ved ein totalproteseoperasjon.» $\mathrm{Og}$ så viste han fram Webers totalprotese (19). Denne hadde tapplager som Christiansens hemiprotese. Primærresultata var gode, men lagtidsresultata svært dårlege (Benum $\mathrm{P}$, personleg melding).

\section{Christiansens totalprotese}

Mot slutten av 1960-åra byrja Christiansen arbeidet med å laga ein totalprotese. Ei arbeidsteikning av tappfôring og hofteskål av Delrin og hoftekule av rustfritt stål er datert 7. februar 1970. Christiansens totalprotese (fig 3c) vart mykje nytta i Skandinavia og - ikkje minst - i Italia. Ifylgje Dumbleton var det innan utgangen av 1977 sett inn om lag 7000 slike protesar - med svært gode resultat (20).

Ved Kysthospitalet i Hagevik kunne dei ikkje heilt einast om kva totalprotese dei skulle satse på. Assisterande overlækjar Milan Rait (1924-2011) trudde på Charnleyprotesen, sjefen sjølv, Otto BrinchmannHansen (1908-84), på Christiansens protese. Frå 1974 sette dei difor inn Charnley-protese og Christiansens protese på annakvar pasient, 200 pasientar i alt, men etter eitt år slutta dei med Christiansens protese av di denne gav dårlege resultat.

Brinchmann-Hansen og medarbeidarane Rait, Lunde og Mølster la fram eittårsresultata sine på eit møte i Norsk ortopedisk forening på Sophies Minde Ortopedisk Hospital 18. november 1978 - ingen reviderte i Charnley-gruppa, mot $5 \%$ i Christiansengruppa. Diverre hadde Rait operert dei aller fleste i Charnley-gruppa og BrinchmannHansen dei fleste i Christiansen-gruppa. Møtedeltakarane kritiserte difor studien, og Christiansens protese vart brukt som tidlegare ved svært mange norske sjukehus, sjølv om korttidstidsresultata for både hemiprotesen og totalprotesen ikkje var heilt gode.

Då ein av forfattarane (Sudmann) året etter vart tilsett som administrerande overlækjar ved Kysthospitalet i Hagevik, måtte han løysa eit administrativt, fagleg og medmenneskeleg problem. Mange pasientar fekk nemleg sett inn Christiansens totalprotese både ein og to gonger i same hofta ved andre sjukehus. Så kom dei seinare til Kysthospitalet og fekk denne bytt ut med ein Charnley-protese. For å framskaffe fakta som kunne stogga denne uheldige praksisen etterundersøkte ein dei pasientane som var med i den prospektive hoftestudien til Brinchmann-Hansen og medarbeidarar.

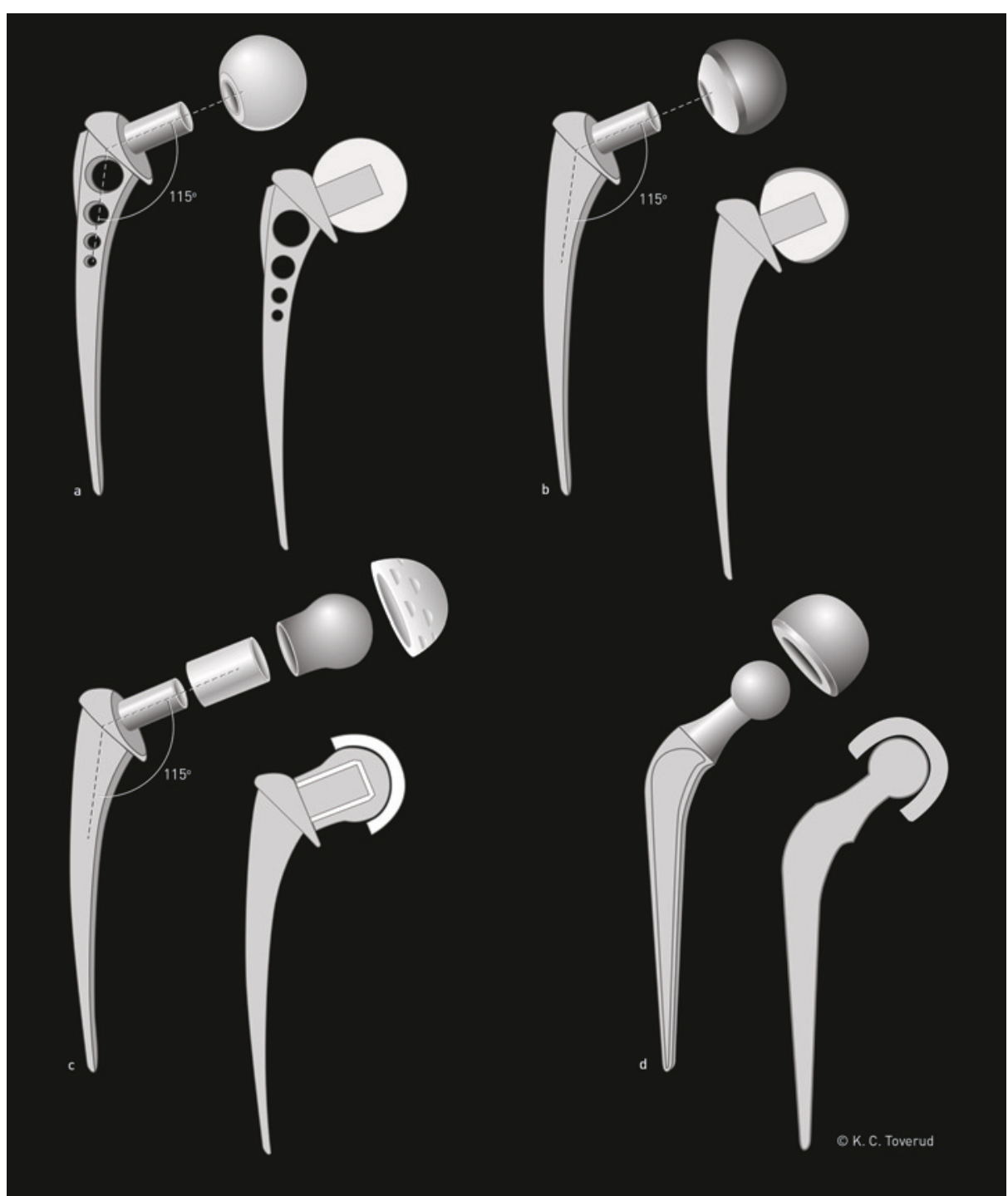

Figur 3 al Christiansens hemiprotese brukt iåra 1965-67. Ei laus hoftekule artikulerer med ein sylinderforma tapp på proteseskaftet, tapplageret. For varande feste i lårbeinskanalen hadde protesestammen fleire gjennomgåande hol, som ein Austin Moore-hemiprotesestamme. Hola skulle tillate innvokster av beinvev for å feste stammen varande til knoken. Tapp-skaft-vinkelen er $115^{\circ}$. Hoftekula var først laga av teflon, frå 1967 av polyetylen. b) Christiansens hemiprotese brukt frå 1968. Den lause hoftekula, pålagt rustfri stålkappe ved Polaris fabrikken på Sandnes, var først laga av polyetylen, så av Delrin. Glatt stamme for sementering. c) Christiansens totalprotese brukt frå 1970. Den relativt store hoftekula av metall artikulerer på innsida mot ei laus fôringshylse av Delrin og på utsida mot ei relativt tunnvegga, kunstig hofteskål av Delrin. Hofteskåla har små utsparingar på utsida for feste til sementen. Glatt stamme for sementering. d) Moderne Charnley-Hastings hemiprotese med laus hoftekule av polyetylen pålagt stålkappe. Hoftekula artikulerer mot ein standard Charnley-stamme med lite hovud, og stålkappa - som på alle andre hemiprotesar - mot leddbrusken i acetabulum. Ein slik «ball and socket joint», bipolar hemiprotese, fekk Christiansen amerikansk patent på i 1969

Resultata av etterundersøkinga vart lagt fram på eit møte i Norsk ortopedisk forening på Sophies Minde Ortopedisk Hospital 24. april 1982. Undersøkinga viste berre $4 \%$ reviderte hofter i Charnley-gruppa, mot $31 \%$ i Christiansen-gruppa. Møtelyden vurderte desse resultata noko ulikt. Overlege Rolf Hagen (1925-2002), Martina Hansens Hospital, meinte at ein kring $10^{\circ}$ større tappskaft-vinkel burde kunna betre langtidsresultata for Christiansens protese. Denne modifiserte protesen hadde Benoist Girard
\& Co alt sett i produksjon, og Hagen hadde fått med seg mange norske avdelingar i ein prospektiv studie. Men det tok likevel ikkje så mange månadane før desse avdelingane slutta med Christiansens protese og byrja bruka Charnley-protesen. Resultata frå Kysthospitalet i Hagevik vart publisert i 1983 (21). Før dette arbeidet, som førte til at all produksjon og alt sal av Christiansenprotesane vart stogga for godt, hadde det vorte sett inn om lag 6500 av desse protesane i Noreg (22). 

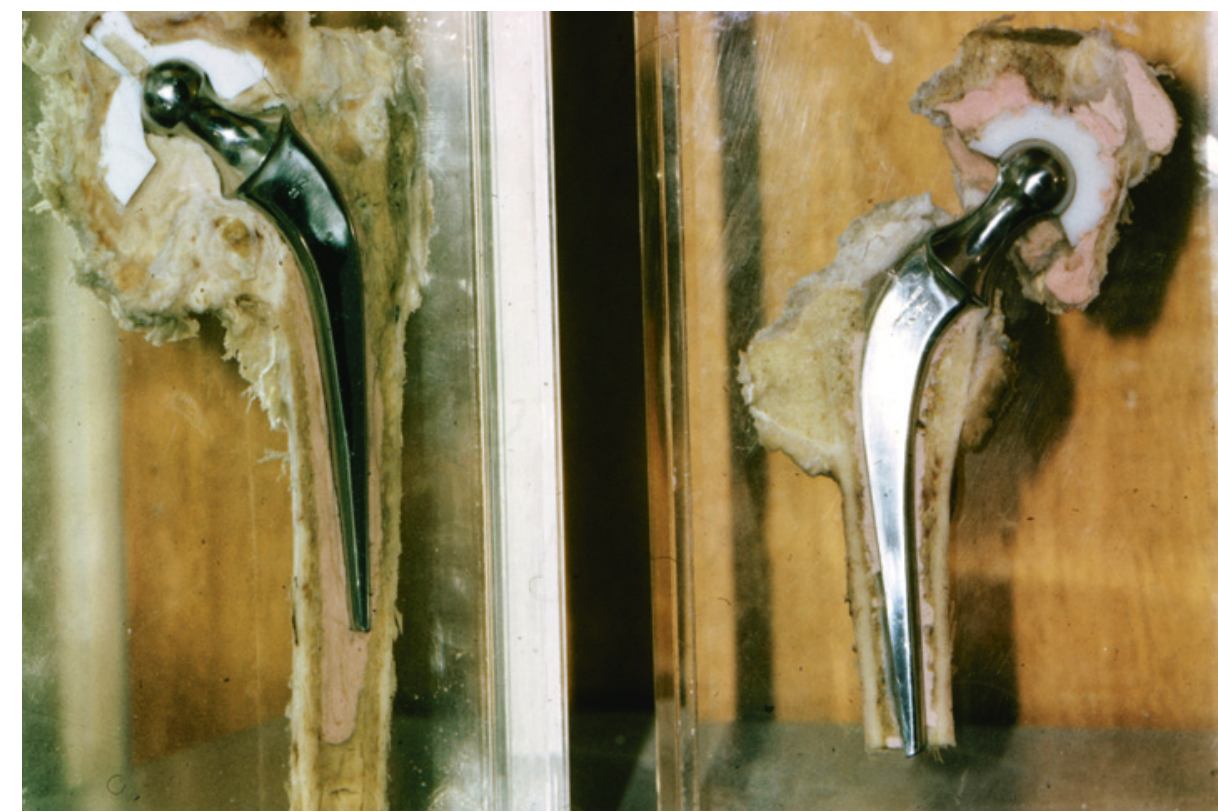

Figur 4 To obduksjonspreparat. Til venstre utsliten teflonhofteskål etter nokre års bruk. Merk vertikal slitasjeveg. Til høgre den framtidsretta protesen med hofteskål av polyetylen med ultrahøg molekylvekt som Charnley tok i bruk i 1962. Fotografert i april 1967 då Sudmann vitja Charnley. Foto: Einar Sudmann
Protesane til Christiansen gav ikkje gode langtidsresultat, men det bør nemnast at enkelte andre protesar var like dårlege, eller dårlegare. Ved Kysthospitalet i Hagevik vart det $i$ åra 1977-84 sett inn 145 av Wagners skallprotesar (23). Etter 10 år var $75 \%$ reviderte (Meyer HK, personleg melding).

\section{Kunne det gått betre?}

I ettertid kan ein undrast korleis langtidsreultata til hofteprotesane hans hadde vorte om Christiansen hadde halde fast ved polyetylen og ikkje bytt denne ut med Delrin, eller brukt den bipolare «ball and socket joint»-hemiprotesen (fig 3d) han fekk amerikansk patent på.

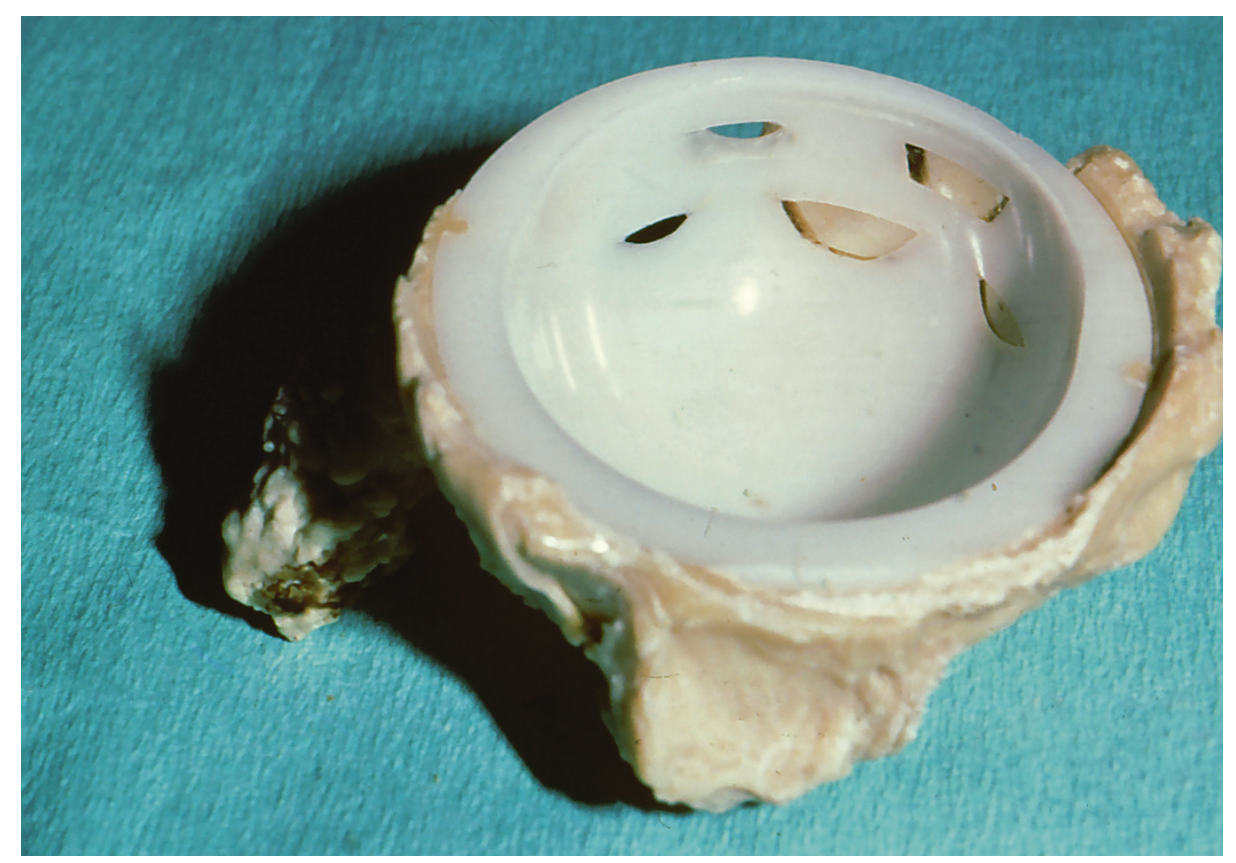

Figur 5 Christiansen-protese revidert ved Kysthospitalet i Hagevik. Delrin-koppen er asymmetrisk sliten tvers igjennom. Denne koppen (utan sementen) nytta Leif Ivar Havelin og medarbeidarar som illustrasjon om slitasje i Christiansen-protesar (25). Slik asymmetrisk koppslitasje går også att i den Christiansen-protesen som Nasjonalt register for leddproteser nyttar som logo. Foto: Einar Sudmann
Dei første prototypane av hemiprotesen vart laga ved ein verkstad i Drammen. Der kunne dei utan vanskar lage eit tapplager, men neppe eit «ball and socket»-ledd. Me reknar difor med at denne løysinga vart lagt til som vanleg sikring ved patentkrav av patentforvaltaren hans i USA. Slik sikring er også bygd inn i kravet til tapp-skaft-vinkelen, krav mindre enn $135^{\circ}$, illustrert $115^{\circ}$ (15).

Som Charnley valde Christiansen først teflon. In vitro var dette kunststoffet bra (og det kunne dessutan steriliserast i autoklave), men det var ubrukeleg in vivo. Deretter prøvde Christiansen polyetylen med høg molekylvekt. Polyetylen kunne ikkje autoklaverast. Her i landet desinfiserte ein difor hoftekula natta over i aktivert dialdehydløysing, Cidex.

Av korrespondanse mellom Christiansen og Polaris går det fram at fabrikken i Sandnes hadde vanskar med å maskinera polyetylen utan avvik frå serie til serie, for stoffet endra lett dimensjonar ved varierande temperatur. Dessutan klaga dei over at restar etter maskineringa, som olje, lett festa seg til det ferdige produktet. Og polyetylen var svaert vanskeleg å maskinere i høve til Delrin. I brevet frå Polaris 7. september 1970 såg dei difor gjerne polyetylen erstatta med Delrin. Først då Christiansen tok i bruk Delrin-hoftekuler, vart desse produksjonsvanskane borte.

Delrin var ikkje berre enklare å forma, det var sjølvsmørjande og av den grunn mykje nytta til lager i industrien. Motstanden mot krymping var berre tiandeparten av motstanden til polyetylen med ultrahøg molekylvekt. Kunststoffet var om lag fire gonger hardare og soleis meir motstandsdyktig mot bein- eller sementbitar i eit kunstig hofteledd (20). Og det kunne, som termoplastisk polymer laga ved polymerisering av formaldehyd, kanskje førebyggje lokal infeksjon. Endeleg kunne det autoklaverast, rett nok med ei lita metallhylse i fôringa til tapplageret for å unngå krymping.

Professor John Scales frå England (1920-2004) (24) tok i både skrift og tale til orde for bruk av Delrin. Og ved personleg samtale med ein av forfattarane (Ramstad) i Drammen gav han uttrykk for kor lite han tykte om konseptet til Charnley. Ramstad bar desse opplysningane vidare til Christiansen på Kongsberg. Det var difor ikkje så rart at Christiansen forlet polyetylenet og byrja med Delrin.

Metall mot plast gjev plastslitasje. Havelin og medarbeidarar påviste til dels svær asymmetrisk slitasje i reviderte Christiansen-protesar (fig 5) (25). E.B. Mathiesen ved Karolinska Institutet fekk tilgang til reviderte hofteskåler og biopsiar 
tekne ved hofterevisjonar ved Kysthospitalet i Hagevik. Han viste for det første at det var dobbelt så stor friksjonsmotstand i Delrin-skåler som i polyetylen-Charnleyskåler og for det andre at Delrin-partiklane gav mykje større vevsreaksjon enn partiklar frå polyetylen med ultrahøg molekylvekt $(26,27)$.

På nytt viste det seg soleis at eit kunststoff med svært gode eigenskapar in vitro kunne gje dårlege resultat in vivo. Dette førde til at Sudmann i tale og skrift tok til orde for at vi trong eit nasjonalt leddregister til liks med grannelanda Sverige og Finland (28).

Nasjonalt register for leddproteser I samband med det årlege frakturkurset på Voss, Vossakurset, i februar 1983 inviterte Sudmann nokre av instruktørane til kveldssete der strategien for etablering av eit norsk leddproteseregister vart drøfta. Det vart semje om at Sudmann skulle fronte eit nasjonalt hofteregister overfor Norsk ortopedisk forening, Helsedirektoratet og Sosialdepartementet.

Han fekk god støtte i sin lobbyaktivitet av Tore Grønmark, dåverande formann i foreninga, og i Helsedirektoratet av saksbehandlaren overarkitekt Jacob Nordan. Fysisk skulle ein freista å leggje registreringa til Haukeland sykehus i Bergen, der assistentlækjar Lars B. Engesæter skulle stå for det praktiske arbeidet.

På årsmøtet til Norsk ortopedisk forening i oktober 1983 vart framlegget til Sudmann om oppretting av eit nasjonalt register vedteke. Etter omfattande arbeid med registreringsskjema, databasar og fleire prøveregistreringar ved Kysthospitalet i Hagevik, Haukeland sykehus, Sentralsjukehuset i Rogaland og Regionsykehuset i Trondheim starta den offisielle registreringa 17. september i 1987.

Det var arbeidet til Christiansen med dislokerte mediale collumfrakturar som - indirekte - gjorde at me fekk eit internasjonalt svært kjent og respektert nasjonalt register for leddprotesar ved Haukeland universitetssjukehus (29). Christiansens protese, med asymmetrisk slitasje av acetabularkoppen, er logoen til registeret. Frå og med året 2005 byrja også ei landsomfattande registrering av alle operasjonar av hoftebrot. Ringen var slutta!

\section{Einar Sudmann (f. 1932)}

er spesialist i generell og ortopedisk kirurgi og professor emeritus ved Universitetet i Bergen. Han var administerande overlækjar ved Kysthospitalet i Hagevik og lærte Christiansens hemiprotese å kjenne via Knut Rasmus Ramstad.

Forfattaren har fylt ut ICMJE-skjemaet og oppgjev ingen interessekonfliktar.

\section{Knut Rasmus Ramstad (f. 1930)}

er spesialist i generell og ortopedisk kirurgi. Han var overlækjar ved Nordland sentralsykehus, Bodø, og samarbeidde tett med Christiansen om utforminga av hemiprotesane hans. Forfattaren har fylt ut ICMJE-skjemaet og oppgjev ingen interessekonfliktar.

\section{Lars Birger Engesæter (f. 1948)}

er spesialist i generell og ortopedisk kirurgi. Han er professor ved Universitetet i Bergen og leiar for Nasjonalt register for leddproteser (NRL).

Forfattaren har fylt ut ICMJE-skjemaet og oppgjev ingen interessekonfliktar.

\section{Litteratur}

. Sudmann E. Thor Aas Christiansen in memoriam Tidsskr Nor Lægeforen 1981; 101: 1299.

2. Ramstad KR. Fractura pertrochanterica et frac tura colli femoris. Tidsskr Nor Lægeforen 1966 ; 86: $1619-23$

3. Deyerle WM. Plate and peripheral pins in hip fractures: two-plane reduction, total impaction, and absolute fixation. Curr Pract Orthop Surg 1966 3: $173-207$

4. Pauwels F. Der Schenkelhalsbruch ein mechanisches Problem: Grundlagen des Heilungsvorganges Prognose und kausale Therapie. Stuttgart: Ferdinand Enke 1935

5. Christiansen T. A new hip prosthesis with trunnion-bearing. Acta Chir Scand 1969; 135: 43-6.

6. Ramstad KR. A new hip prosthesis: preliminary report. A survey of indications and results in 90 patients. Acta Chir Scand 1969; 135: 47-50.

7. Goldie IF, Raner C. Total hip replacement with a trunnion bearing prosthesis. Biomechanical principles and preliminary clinical results. Acta Orthop Scand 1979. 50: 205-16.

8. Hofteleddsprotese laget på skipsverft. Uvanlig spesialitet ved A/S Nymo. Fædrelandsvennen 1972: 1.

9. Charnley J. Arthroplasty of the hip. A new operation. Lancet 1961; 1: 1129-32.
10. Charnley J. Tissue reactions to polytetrafluorethylene. Lancet 1963; 282: 1379.

11. Charnley J. An artificial bearing in the hip joint: implications in biological lubrication. Fed Proc 1966; 25: 1079-81.

12. Charnley J. Low friction arthroplasty of the hip. Theory and practice. Berlin: Springer-Verlag. 1979.

13. Kavlie H, Norderval Y, Sundal B. Femoral head replacement with the christiansen endoprosthesis. A follow-up study, and a report on 175 arthroplasties with the present model of the prosthesis with acrylic cement fixation. Acta Chir Scand 1975; 141: $96-103$

14. Nesse E, Ramstad KR. Christiansens hemiprotese. Et ti års materiale. Tidsskr Nor Lægeforen 1989; 109: $2136-8$

15. Unites States patent US 3466670. Christiansen T. HIP-JOINT PROSTHESIS. 1969; 1-3. www.google. it/patents/US3466670 (31.10.2013)

16. Devas M, Hinves B. Prevention of acetabular erosion after hemiarthroplasty for fractured neck of femur. J Bone Joint Surg Br 1983; 65: 548-51.

17. Wetherell RG, Hinves BL. The Hastings bipolar hemiarthroplasty for subcapital fractures of the femoral neck. A 10-year prospective study. J Bone Joint Surg Br 1990; 72: 788-93.

18. Frihagen F, Figved W, Madsen JE et al. Behandling av lårhalsbrudd. Tidsskr Nor Legeforen 2010; 130: 1614-7.

19. Weber BG. Total hip replacement with rotationendoprosthesis. [Trunnion-bearing prosthesis] Clin Orthop Relat Res 1970; 72: 79-84

20. Dumbleton JH. Delrin as a material for joint prosthesis - a review. I: Acharya A, Syrett BC, red. Corrosion and degradation of implant materials. Baltimore: ASTM, 1979: 41-60

21. Sudmann E, Havelin LI, Lunde OD et al. The Charnley versus the Christiansen total hip arthroplasty. A comparative clinical study. Acta Orthop Scand 1983; 54: 545-52.

22. Engesaeter LB, Furnes A, Havelin LI et al. Hofteregisteret. God samfunnsøkonomi. Tidsskr Nor Lægeforen 1996; 116: 3025-7.

23. Wagner H. Surface replacement arthroplasty of the hip. Clin Orthop Relat Res 1978; nr. 134: 102-30.

24. Orbituary: Professor John Scales. Times Online 2004

25. Havelin LI, Gjerdet NR, Lunde OD et al. Wear of the Christiansen hip prosthesis. Acta Orthop Scand 1986; 57: 419-22

26. Mathiesen EB, Lindgren U, Reinholt FP et al. Wear of the acetabular socket. Comparison of polyacetal and polyethylene. Acta Orthop Scand 1986; 57 : 193-6.

27. Mathiesen EB, Lindgren JU, Reinholt FP et al. Tissue reactions to wear products from polyacetal (Delrin) and UHMW polyethylene in total hip replacement. J Biomed Mater Res 1987; 21 459-66.

28. Sudmann E. Eit nytt liv for artrosepasientar Tidsskr Nor Lægeforen 1982: 102: 1431.

29. Nasjonalt register for leddproteser. www.haukeland.no/nrl (31.10.2013).

Motteke 12.8. 2013, første revisjon sendt inn 17.9 2013, godkjent 31.10. 2013. Redaktør: Sigurd Høye. 